\title{
Projeto Assistencial Voltado para o Idoso, Amplia a Prática Humanizada da Instituição
}

\author{
Oliveira, Maridite Cristovão Gomes de; Lino, Ivanise Regina de Paiva; Reis, Maria \\ das Dores; Silva, Ana Paula da; Santos, Iolanda Martins; Cardassi, Claudia Eliza \\ Ricardo \\ Hospital Geral de Sao Mateus — maridite@uol.com.br
}

Introdução Este hospital publico da rede SUS / São Paulo, desenvolveu um projeto piloto voltado para o idoso, com foco na humanização. Estudadas as necessidades específicas desta população, foram construídos os dez passos para um Hospital ser "Amigo do Idoso", baseadas em três eixos: comunicação, acessibilidade e cuidado. Objetivo Demonstrar as mudanças na qualidade da assistência ao idoso a partir de uma abordagem ampla, com os pressupostos da humanização de respeito, autonomia e diálogo. Metodologia Constituiuse um Grupo de Trabalho(GT) multidisciplinar para desenvolver as ações que acolhem o idoso desde sua entrada no serviço, à internação e alta objetivando o resgate da dignidade, respeito e autonomia do idoso como protagonista de seu cuidado. Três linhas de ação foram estabelecidas como método de trabalho: a) grupos focais com participação de profissionais, idosos da comunidade e usuários do serviço; b) sensibilização dos profissionais da instituição; c) capacitação da equipe multiprofissional; Resultados Os passos estabelecidos foram: 1 - Escuta qualificada; 2 - Acolhimento preferencial; 3 Acessibilidade; 4 - Ações de Humanização; 5 - Equipe de voluntários amigo do idoso e capacitação para cuidadores; 6 - Sensibilização dos profissionais; 7 - Ações de prevenção de quedas e violência; 8 - Capacitação da equipe multidisciplinar; 9 - Avaliação multidimensional do idoso e plano de cuidados; 10 - Cuidados inovadores às condições crônicas, incluindo a meditação como promoção de saúde. a partir destes parâmetros houve desdobramento de várias atividades: alta integrada com a rede de serviços de saúde; visita domiciliar com equipe multidisciplinar, cuidados paliativos e assistência à finitude. Conclusões: a abordagem de um projeto, voltado para o indivíduo dentro de uma concepção ampla e humanizadora, permitiu acentuar a diferença do olhar para esta clientela e promover mudanças na prática dos profissionais envolvidos em seu atendimento. Ocorreu o resgate da autonomia e da cidadania do idoso, um despertar para a ressignificação da vida. Verificou-se nesta experiência um novo desabrochar das pessoas, das equipes e da instituição e maior comprometimento dos profissionais na assistência ao paciente idoso. Houve uma mudança de atitude e da cultura institucional.

Oliveira, Maridite Cristovão Gomes de; Lino, Ivanise Regina de Paiva; Reis, Maria das Dores; Silva, Ana Paula da; Santos, Iolanda Martins; Cardassi, Claudia Eliza Ricardo. Projeto Assistencial Voltado para o Idoso, Amplia a Prática Humanizada da Instituição.. In: Anais do Congresso Internacional de Humanidades \& Humanização em Saúde [= Blucher Medical Proceedings, num.2, vol.1]. São Paulo: Editora Blucher, 2014. ISSN 2357-7282

DOI 10.5151/medpro-cihhs-10702 